\title{
Moisture content variation of ground vegetation fuels in boreal mesic and sub-xeric mineral soil forests in Finland
}

\section{Lindberg, Henrik}

2021

Lindberg , H , Aakala , T \& Vanha-Majamaa , I 2021 , ' Moisture content variation of ground vegetation fuels in boreal mesic and sub-xeric mineral soil forests in Finland ', International Journal of Wildland Fire, vol. 30 , no. 4 , pp. 283-293 . https://doi.org/10.1071/WF20085

http://hdl.handle.net/10138/338863

https://doi.org/10.1071/WF20085

unspecified

acceptedVersion

Downloaded from Helda, University of Helsinki institutional repository.

This is an electronic reprint of the original article.

This reprint may differ from the original in pagination and typographic detail.

Please cite the original version. 
1 Moisture content variation of ground vegetation fuels in boreal mesic and sub-xeric

2 mineral soil forests in Finland

3

4 Henrik Lindberg ${ }^{\mathrm{A}, \mathrm{E}}$, Tuomas Aakala ${ }^{\mathrm{B}, \mathrm{C}}$ and Ilkka Vanha-Majamaa ${ }^{\mathrm{D}}$

5

6 AHäme University of Applied Sciences, School of Bioeconomy, Visamäentie 35 A, P.O. Box 230, FI-

713100 Hämeenlinna, Finland

$8{ }^{\mathrm{B}}$ Department of Forest Sciences, Latokartanonkaari 7, P.O. Box 27, FI-00014 University of Helsinki,

9 Finland

$10{ }^{\mathrm{C}}$ Current address: University of Eastern Finland, School of Forest Sciences, P. O. Box 111

11 FI- 80101 Joensuu, Finland

$12{ }^{\mathrm{D}}$ Natural Resources Institute Finland (Luke) Latokartanonkaari 9, FI-00790 Helsinki, Finland

$13 \quad{ }^{\mathrm{E}}$ Corresponding author: Email: henrik.lindberg@hamk.fi

14

15

16

17

18

19

20

21 
23 Abstract: Forest fire risk in Finland is estimated by the Finnish Forest Fire Index (FFI), which

24 predicts the fuel moisture content (FMC) of the forest floor. We studied the FMC variation of four

25 typical ground vegetation fuels, Pleurozium schreberi, Hylocomium splendens, Dicranum spp., and

26 Cladonia spp., and raw humus in mature and recently clear-cut stands. Of these, six were sub-xeric

27 Pinus sylvestris stands, and six mesic Picea abies stands. We analyzed FFI's ability to predict FMC

28 and compared it with the widely applied Canadian Fire Weather Index (FWI).

29 We found that in addition to stand characteristics ground layer FMC was highly dependent on the

30 species so that Dicranum was the moistest, and Cladonia the driest. In the humus layer, the

31 differences among species were small. Overall, the FWI was a slightly better predictor of FMC than

32 the FFI. While the FFI predicted ground layer FMC generally well, the shape of the relationship

33 varied among the four species. The use of auxiliary variables thus has potential in improving

34 predictions of ignitions and forest fire risk. Knowledge of FMC variation could also benefit planning

35 and timing of prescribed burnings.

37 Brief summary: The studied four moss and lichen species were found to dry at different rates, thus having different ignition potential and fire risk. Stand type, and particularly developmental stage also affected the drying rates. The fire risk indices could be improved by using these variables, which could benefit fire prevention.

42 Keywords: fire risk, forest fire index, forest type, prescribed burning, Norway spruce, Scots pine, stand structure

44 Running head: Variation in moisture content of ground vegetation fuels 
49 In Finland, forest fires declined during the last century. This decline was particularly steep during the 50 latter half of the century. The average annual burned area in 1950s was about 5,700 ha and in the 51 1970s it had declined to approximately 700 ha (Yearbook of Forest Statistics 1990-1991 (1992). In 52 recent decades, the average annual burned area has varied between 200 and 800 ha, only occasionally exceeding 1,000 ha. The average size of an individual fire is currently about 0.4 ha (Finnish Statistical

54 Yearbook of Forestry 2014). The climatological fire risk in Finland was relatively stable during the last century (Mäkelä et al. 2012), so the decline in fire occurrence is explained by other factors, such as efficiency in fire detection and suppression, and changes in ignition sources, stand structure, forest fragmentation, and vegetation (Päätalo 1998; Wallenius 2011). This is also supported by the difference between the fire regimes of Finland and neighbouring Sweden, where the annual burned area has been higher and large fires frequent (Lindberg et al. 2020).

Although forest fires do not currently form a major risk to society or property in Finland, they still employ rescue services leading to a need to improve forest fire risk assessment methods. This is partially due to the fact, that although the burned area has been low, the annual number of fires has been about 1,300 in the $21^{\text {st }}$ century (Finnish Statistical Yearbook of Forestry 2014). Thus, the smallsized but frequent forest fires burden regional rescue services and local fire brigades during the forest fire season. Several studies have also predicted that the general forest fire risk in Finland (Kilpeläinen et al. 2010; Lehtonen et al. 2014; Mäkelä et al. 2014) and the risk for large fires (Lehtonen et al.

67 2016) will increase in the $21^{\text {st }}$ century. One way to improve the preparedness of rescue services is to improve the ability to predict potential fire hazard days.

69 The fuel moisture content (FMC) of different fuels is one of the key factors when estimating fire risk.

70 FMC is used to predict flammability, and it is also a factor in models predicting fire intensity and fire

71 spread rate. Most forest fire indices are meteorological and use various weather data to compute

72 indices for assessing fire risk (San-Miguel-Ayanz et al. 2003). 
73 Currently, the most widely used fire index system is the Canadian Forest Fire Weather Index System

74 (CFFWIS), which was initially designed for the Canadian boreal forest. Since being published in 1970

75 (Van Wagner 1987), it has gradually been adopted in many parts of the world, including different

76 vegetation zones and fuel types (Dimitrakopoulos et al. 2011). The FMC estimation in CFFWIS is

77 divided into three moisture codes: Fine Fuel Moisture Code (FFMC), Duff Moisture Code (DMC) and

78 Drought Code (DC) (Van Wagner 1987). These moisture codes are calculated daily based on air

79 temperature, relative humidity (not in DC), wind speed (only FFMC), and rainfall. Two spread

80 indices are then estimated: initial spread index using wind and FFMC and build-up index combining

81 DMC and DC. The spread indices are then combined to determine the Fire Weather Index (FWI) (Van

82 Wagner 1987).

83 CFFWIS has proven suitable in forests with a flammable duff layer typically consisting of a humus

84 layer and moss cover like, for instance, the black spruce (Picea mariana) (Mill.) Britton, Sterns \&

85 Poggenburg) forests in boreal Northern America (e.g. Ziel et al. 2020). Fennoscandian coniferous

86 forests have a similar type of duff structure, and CFFWIS has generally been found to work well there

87 (Granström and Schimmel 1998; Tanskanen et al. 2005).

88 Despite the increasing use of CFFWIS, national fire indices are still commonly used in many

89 countries. In Finland, the forest fire risk is estimated and predicted by the Finnish Forest Fire Index

90 (FFI). FFI was constructed in 1996 to replace the former fire index, which was based merely on

91 statistical correlations between weather variables and the occurrence of fires (Heikinheimo et al.

92 1998). In 1996, Sweden started to use CFFWIS as a national forest fire index system (Sjöström et al.

93 2019), but the Finnish Meteorological Institute (FMI) decided to develop its own index, partly

94 because CFFWIS was considered unnecessarily complicated with its hierarchical structure, and

95 because it was lacking solar radiation as an explaining variable (Heikinheimo et al. 1998).

96 FFI is based on empirical relationships between weather data and the volumetric moisture content of a

97 6-cm thick layer of forest floor. In short (see Supplement 1 and Vajda et al. (2014) for details), air

98 temperature values are obtained from the ground weather station network and spatially interpolated to

99 a $10 \mathrm{~km} \times 10 \mathrm{~km}$ grid using the kriging method (Venäläinen and Heikinheimo 2003). Evaporation is 
estimated based on this interpolated data and weather prediction models, and the precipitation is received from weather radars (Venäläinen and Heikinheimo 2003; Vajda et al. 2014). The index is a continuous variable calibrated to vary from 1.0 to $6.0,6.0$ being the driest. The index has been assigned a threshold value of 4.0 , at which point it predicts a volumetric moisture content under $20 \%$.

When the index exceeds this threshold, a forest fire warning is announced in public media, which forbids the lighting of open fires. It must be noted that the FFI uses volumetric moisture content values based on non-destructive monitoring of fuels and thus they are not directly comparable with

107 gravimetric moisture content values.

In addition to its role in wildfire, FMC plays an important role in prescribed burnings, used in Finland as a silvicultural tool and nowadays also for ecological restoration and management for biodiversity.

110 Because of this, the scope of prescribed burnings in Finland has widened in recent years to a more diverse set of burnings with different ecological aims such as burnings of retention trees, restoration burnings in nature conservation areas and management burnings of sun-exposed and xeric habitats

113 (for details see Lindberg et al 2020). The various aims also set diverse targets for fire impact and depth. However, despite the recognized importance of fire for restoration, the overall area of prescribed burns has declined in recent decades (Lindberg et al. 2020).

117 FMC is one of the most significant factors determining the potential days of prescribed burnings and 118 intended burning depth (Sandberg 1980; Ferguson et al. 2002; Hille and den Ouden 2005; Hille and 119 Stephens 2005). Because of different ecological aims, understanding how FMC develops in various fuels and their effect on fire impact and burning result is necessary. As an example, in silvicultural burnings and burnings on barren habitats, the aim is to decrease the organic layer, which requires a sufficiently low FMC. If the moisture of the ground layer and in some cases raw humus is too high,

123 the burning effects are not fully achieved. In restoration burnings, more various moisture conditions 124 are possible, since more diverse burning results are accepted (Lindberg et al. 2020). 
Boreal ground layer species differ in their structure and growth form which affects their water-holding capacity (Peterson and Mayo 1975; Busby and Whitfield 1978; Pech 1989). The aim of this study was

127 to determine the FMC variation of dominant forest floor mosses and lichens and raw humus in different stands of the two most common forest types in Southern Finland. We analyzed how the moisture content of selected species varied as a function of FFI, and we compared the ability of FFI and FWI to predict the FMC of selected fuel materials.

131 We hypothesize that as clear-cut areas and pine-dominated sub-xeric stands receive more radiation and are more exposed to the drying effect of wind: i) ground vegetation fuels dry faster in clear-cut areas as compared to closed-canopy forests, ii) fuels in pine-dominated forests dry faster than in spruce-dominated forests, iii) varying water holding capacity of studied materials explains the possible differences in their FMC behavior and potential days of ignition.

\section{Materials and methods}

Study area

The study area is located in Southern Finland in the Evo State Forest (Fig. 1) belonging to the southern boreal vegetation zone (Ahti et al. 1968). The elevation of the study area varies between

142 100-190 meters a.s.l., mean annual temperature in the region is $+3.1^{\circ} \mathrm{C}$, the average annual

143 precipitation is $670 \mathrm{~mm}$, and the growing season 160 days (Juvakka et al. 1995). The bedrock is

144 mostly orogenic granitoid covered by a thick, stony morainic layer, but glacier sedimented areas such 145 as deltas, sandur deltas and eskers with sand or gravel are also common (Okko 1972). Of the sampled 146 stands, the sub-xeric stands were mostly located in sedimented, sandy soils and mesic stands on sandy 147 or fine sandy moraines (Fig. 1).

\section{$149 \quad$ Figure 1}


153 Nearly $90 \%$ of Finnish forests are managed commercially (Finnish Statistical Yearbook of Forestry

154 2014). The management is typically done relatively uniformly, including artificial regeneration, 2-4

155 low thinnings, and clear-cutting with less than 3\% retention of tree volume (Finnish Forestry, Practice

156 and Management 2011, Kuuluvainen et al. 2019). The stands are thus evenly aged, relatively sparsely

157 stocked and most often dominated by Norway spruce (Picea abies L.) H. Karst and Scots pine (Pinus

158 sylvestris $\mathrm{L}$.

159 The most common forest site types on mineral soils in Finland are mesic forests (Myrtillus-type),

160 which cover $52 \%$ and sub-xeric forests (Vaccinium-type), which cover $26 \%$ of forests (Finnish

161 Statistical Yearbook of Forestry 2014).

162 Both forest types in their later successional stages are characterized by dwarf shrubs bilberry

163 (Vaccinium myrtillus L.), lingonberry (Vaccinium vitis-idaea L.) and common heather (Calluna

164 vulgaris L. (Hull)). In sub-xeric forests V. vitis-idaea and Calluna are dominant, and in mesic forests

165 V. myrtillus is dominant and Calluna practically absent.

166 Managed conifer-dominated mesic and sub-xeric forests on mineral soils typically have an easily

167 distinguishable raw humus layer with a typical thickness of 3-5 cm in Southern Finland (Tamminen

168 1991). In these forests, moss and lichen dominated ground vegetation is the most common and the

169 most important flammable fuel bed, where the majority of forest fires ignite and spread (Schimmel

170 and Granström 1997; Tanskanen et al. 2005). A continuous moss carpet is typical in later

171 successional stages of coniferous forests whereas in young successional stages it is less abundant, thus

172 decreasing fire risk (Schimmel and Granström 1997). Yet, recent clear-cuts where the moss carpet

173 still exists and herbs and graminoids have not yet colonized the areas are flammable similar to the

174 mature forests. A recent study showed that a significant number of forest fires in Sweden are started

175 in clear-cuts as the sparks produced by forest machines are an important source of ignitions (Sjöström

176 et al. 2019). The raw humus layer is also potentially flammable, and the targets and success of

177 prescribed burnings are often estimated by burning depth, which indicates the decrease of moss and

178 raw humus layer. 
179 The feather moss (Pleurozium schreberi) (Brid) Mitt. is the most abundant moss species with a 180 coverage of approximately $30 \%$ in mesic and 35\% in sub-xeric forests. (Mäkipää 2000a). Fork mosses

181 (Dicranum spp., D.polysetum Sw. and D.scoparium Hedw. being the most dominant) cover about 10\% 182 in both mesic and sub-xeric types (Mäkipää 2000b), whereas stairstep moss (Hylocomium splendens) 183 (Hedw.) is clearly more abundant in mesic types with a share over 10\% but in sub-xeric types only 184 3\% (Mäkipää 2000c). Reindeer lichens (Cladonia spp) are practically absent in mesic forests but 185 patchy with an average share of 5\% in sub-xeric forests (Nousiainen 2000). Cladonias abundance 186 increases significantly in xeric and barren forests, which are less common (pooled share 4\%) and are concentrated in Northern Finland (Finnish Statistical Yearbook of Forestry 2014).

Twelve forest stands from the study area were chosen, consisting of four different stand types and three replicates from each. The stand types were: 1 . Sub-xeric, mature, Pinus dominated stand. 2. Subxeric, clear-cut area. 3. Mesic, mature, Picea dominated stand. 4. Mesic, open, clear-cut area (Fig. 1, Table 1). The age and standing stock of a stand is referred to as the developmental stage (either clearcut or mature) and the combination of forest type and dominant tree species as stand type (either subxeric/Pinus or mesic/Picea) (Table 1).

We selected individual stands from the forest planning databases of the study area, according to the following criteria: mature stands had to be over 70 years of age and be either Pinus- or Piceadominated, with at least $70 \%$ dominance (Table 1). The clear-cut stands had to be harvested during the previous winter with no mechanical scarification. All stands had a distinctive raw-humus layer and a characteristic continuous moss layer with patches of Cladonia in sub-xeric stands. The growing stock and structure of the mature stands represented typical Finnish managed forest stands with an evenly aged structure and minor understory. 
From each stand, samples of three dominant moss and/or lichen species were collected on 17 days during summer 2003. The days were chosen using FFI values received from the Finnish Meteorological Institute, so that they would cover different weather and drying conditions (Fig. 2). Sampling was focused especially on dry and drying periods whereas, during constant wet periods (which covered the most part of the sampling period), it was not carried out.

We sampled each stand in the afternoons of the sampling days. On each occasion, five randomly chosen samples consisting of moss or lichen and raw humus were taken with humus auger with a diameter of $5.8 \mathrm{~cm}$, height of $10 \mathrm{~cm}$ and volume of $264 \mathrm{~cm}^{3}$ The samples' were taken from a $300 \mathrm{~m}^{2}$ circular sample plot and were located at least $30 \mathrm{~m}$ from the stand edge. In mesic stands, the sampled species were: Pleurozium.schreberi, Dicranum spp (D. polysetum being the most abundant) and Hylocomium splendens., and on sub-xeric stands Pleurozium, Dicranum and Cladonia. (C. rangiferina (L.) Weber ex F.H. Wigg. being the most abundant). The third replication of mesic clearcut area had an insufficient cover of Hylocomium, so only Pleurozium and Dicranum were sampled.

Each sample was then divided into two layers: surface and raw humus. Five subsamples of each layer were pooled into one sample representing the average from that stand. Thus, each sampled stand had six combined samples: a combined sample of each of the three surface species, and three combined samples from raw humus under each species. The collective samples were preserved during transportation in air-tight plastic bags. The fresh-weighing and drying was done directly after transportation with a minimum of 18 hours of oven-drying at $105^{\circ} \mathrm{C}$. Sufficient drying time was ensured by experimental dryings before actual sampling. After drying, the samples were weighed and the dry-weight FMC was determined.

Data analysis

The noon values of FFI and FWI were used in analysis. The FWI values were received from FMI and calculated according to Van Wagner and Pickett (1985) using weather data from the nearest 
meteorological station located approximately $4 \mathrm{~km}$ south-west of the center of the study area. The wind values came from the nearest available station, about $25 \mathrm{~km}$ north-east of the study area. We modeled FMC separately for each species, and the surface and raw humus layers, as a function of FFI, stand type, and the development class. Preliminary analyses showed that the shape of the relationship between FMC and FFI varied among the species and was often non-linear. We thus used generalized additive modeling (e.g. Zuur et al. 2009), in which FMC was predicted as a smooth function of FFI.

240 For the strictly positive data (FMC), we used a Gaussian error distribution and log-link function, and

241 the smoothers were allowed to vary as a function of developmental stage. To avoid problems with 242 overfitting and to ensure biologically realistic model behavior, we used monotonically decreasing Psplines as smoothers and limited their flexibility (number of knots in the splines $k=4$ ). To compare the performance of FFI to the more widely used FWI, we then repeated the analyses, using FWI as the continuous predictor in place of FFI. The models were compared using pseudo- $\mathrm{R}^{2}$ values for both (models with FFI and FWI). For model validation (sensu Zuur et al. 2009), we visually inspected the residuals as a function of FMC and each predictor, as well as day of year to ensure there were no temporal patterns in the residuals (Supplement 2). All models were fitted using R ( $\mathrm{R}$ Core Team 2019) and the package scam (Pya 2018).

The observed and predicted days of ignition of surface fuels in different stands were analyzed by calculating a probability using FMC frequencies. In Fennoscandia, the FMC values for moisture content of extinction have been estimated to range from 25 to $35 \%$ (Granström and Schimmel 1998; Tanskanen et al. 2005). We used the lower limit since it was considered a more suitable estimate for the timing of prescribed burnings, which was justified because in prescribed burnings one aim is to decrease organic material and ensure a sufficient ecological impact (Lindberg et al. 2020). The frequencies over threshold value were compared to all the values of the examined variables or their combinations. Thus, if for instance Pleurozium in sub-xeric clear-cuts had 21 observations under a $25 \%$ threshold value of FMC, these 21 were compared to all 51 observations in sub-xeric clear-cuts resulting in a probability ratio of $41 \%(21 / 51) \times 100=41 \%)$. 
264 During the measurement period, the FMC of surface layer varied between 3\% and 300\% (Fig. 2). The overall patterns in how the moisture conditions changed during the summer were similar among the species, sites and site types, but the levels differed greatly among species and sites (Fig. 2). It should be noted that the weather conditions during summer 2003 were relatively variable with no long dry periods. This is visible in the distribution of the FFI values, where the highest values (4-6) are missing, which means that the driest circumstances did not occur during sampling (Fig. 2).

Of the species, Dicranum was generally the moistest and Cladonia the driest, whereas Pleurozium and Hylocomium were between the two. When modeling the FMC as a function of FFI, stand type and developmental stage, several patterns were visible in the surface layer. First, there were clear differences between species in the shape of the relationship between FMC and FFI. Pleurozium, Hylocomium and Cladonia had a tendency for a steadier decline compared to Dicranum, which retained moisture up to a higher FFI before declining more rapidly in moisture content (Fig. 3). It is noteworthy that, despite the quick decline at higher FFI values for Dicranum, the predicted moisture content in mature stands stayed above the 25-35\% level, considered a threshold of ignition (Fig. 3). Stand type was not a significant predictor for any of the species in the surface layer (Table 2). The effect of the developmental stage was significant in the smoother terms only (Table 3, Fig. 4). Plotlevel random effects were significant only for Pleurozium.

For the raw humus layer, the relationship between FFI and fuel moisture content were close to linear in most cases, and the differences in the smoothers were clearly smaller compared to the surface layer (Table 2). Similarly, the effect of stand type was different from the surface layer so that, for both 
random effects were significant only for Cladonia. The raw humus variation among the stand types

Table 2

\section{Table 3}

$294 \quad$ Figure 3

Figure 4

FWI predicted the FMC of surface layers slightly better than FFI (Table 4). Both models predicted the

FMCs of Pleurozium and Hylocomium better than Dicranum and Cladonia. In raw humus, the prediction ability was clearly lower, and FWI and FFI performed practically equally (Table 4). The predicted moisture variation curves as a function of FWI are shown in Supplement 3.

301

\section{Table 4}

303

The potential fire hazard days (i.e., days during which the FMC values were under 25\%) were highest in Cladonia and lowest in Dicranum (Table 5). Clear-cut areas and sub-xeric pine stands had more fire hazard days than mature stands and mesic spruce-stands. The predicted fire hazard days by FFI formed $6 \%$ of sampled days, whereas the observed FMCs of $>25 \%$ during the same sampled days was $28 \%$.

\section{Table 5}

\section{Discussion}

314 Our results showed that the composition of ground floor vegetation has an effect on the flammability

315 of the surface layer in Fennoscandian boreal forests, and how it varies during the fire season. This

316 flammability was further modulated by the effect of stand growing stock along the lines shown in 
317 earlier studies (Granström and Schimmel 1998; Tanskanen et al. 2005; Tanskanen et al. 2006). The

318 differences among species and developmental stages in how the surface layer moisture varied were

319 prominent. As an example, Dicranum in mature stands retained a moisture content well above the 25-

$32035 \%$ threshold of the FFI value of 4 (the threshold for public warning), whereas Cladonia was close to

321 the flammability threshold throughout the range of FFI values included in the sample here.

322

323 The development of moisture content between the surface layer and raw humus was clear. Rain

324 usually affects the surface layer saturating it rapidly. The raw humus layer receives some moisture,

325 especially in heavier rains, but dries slowly. However, during longer dry periods, the surface layer and

326 raw humus dry more thoroughly. Long drought periods did not occur during the sampling period so

327 the FMCs in such circumstances could not be compared.

328

329

The FMC variation of surface and raw humus layers was great, especially in higher FMCs, which can be due to several reasons. The same FFI values estimated for a $10 \mathrm{~km} \times 10 \mathrm{~km}$ square were used for all stands, so differences in rainfall between stands may have occurred due to local showers. The FMCs were determined layer by layer, which overlooks moisture variation within layers. It is known that the moisture gradient within layers is steep (Vasander and Lindholm 1985), so the upper parts of the surface layer could be clearly drier than the FMCs observed in this study.

335

When considering differences among the species in the surface layer, Dicranum was consistently the moistest, and Cladonia the driest. Pleurozium and Hylocomium were between these two and showed a relatively similar moisture behavior as presented by Busby and Whitefield (1978). The higher FMCs and slower drying curve of Dicranum is probably due to its dense tomentum-covered structure (Peterson and Mayo 1975), which leads to a higher moisture retaining capacity. As reported previously (Mutch and Gastineau 1970; Granström and Schimmel 1998), Cladonia was the driest surface fuel. This is explained by its gelatinous thallus, loose structure and high surface-to-volume ratio resulting in extreme moisture behavior (Heatwole 1966; Pech 1989, 1991). 
FMC varied among stand types. The results of the FMC variation of the surface layer are in accordance with previous studies in which the differences between stands correlate with their ground

347 vegetation flammability (Tanskanen et al. 2006). Using 30\% threshold values for the FMC of moss

348 layer, Tanskanen et al. (2006) reported two times more potential days of ignition in open than in mature areas, and in Pinus-dominated stands two to three times higher than in Picea-dominated stands. In our study, the differences between clear-cut and mature developmental stages were clear, but the impact of site type and the associated dominant tree species was smaller.

Comparison between the Finnish FFI and Canadian FWI showed that FWI was consistently a better predictor for the moisture content of the surface layer fuels, irrespective of the species. For the raw humus layer, the two indices performed almost identically. The better performance of FWI for surface fuels was similar to what Tanskanen et al. (2005) reported. Thus the CFFWIS could well be used in Finland.

Our results support the conclusions of Tanskanen et al. (2005) and Vajda et al. (2014) suggesting that FFI could be improved by using forest stand variables. Such parameters as developmental stage and dominant tree species could likely improve the FFIs prediction ability significantly, which could eventually help practical fire suppression activities by better anticipation and preparation.

Fire history studies in Fennoscandia have reported great variation in fire cycles. The shorter cycles have been typical in Pinus-dominated forests, especially in south- and middle boreal forests (e.g., Lehtonen and Kolström 2000), whereas in more northern and Picea-dominated forests, the cycle has been longer (e.g. Wallenius 2004). The differences have been explained by meteorological factors, dominant tree species, vegetation, fire suppression and general human influence (Wallenius 2004, 2011). According to our results, the differences in reported fire cycles could be partially explained by dominant tree species and changes in ground floor vegetation, especially in lichen-bryophyte ratio. For example, the abundance of Cladonia has substantially decreased in recent decades in Finland (Nousiainen 2000; Mäkipää and Heikkinen 2003; Tonteri et al. 2013). At the same time, a notable increase in the abundance of Dicranum has been documented especially in Northern Finland

371 (Mäkipää 2000b). It is possible that reduction in the cover of fast-drying Cladonia and increase in the 
372 cover of slowly-drying Dicranum has partially reduced forest fire risk particularly in Northern

373 Finland.

374

375 In our study, the large variation of FMC in different stands and ground floor fuel materials show that potential days for prescribed burnings also have a large variation, especially when the variable ecological targets of burnings are taken into account. An often presented rule of thumb in guidelines for prescribed burnings is that the forest fire warning in Finland (FFI value 4) could be considered as a general threshold for successful burnings (Lemberg and Puttonen 2002). According to our results, this assumption is too simplistic, since suitable days for prescribed burning also seem to occur with lower FFI values. Yet it should be noted that the selected level of FMC 25\% should be interpreted as a level where burning of studied surface layer fuels is possible. Thus, the various goals of prescribed burnings should be taken into account when suitable burning conditions are determined. For instance, in most restoration burnings no special burning depth is targeted as it is in silvicultural burnings. On the other hand, denser stands where restoration burnings are performed dry slower than regeneration areas. Also, if the aim is also to burn the humus layer, long drought periods are needed since the FMC values of raw humus did not reach the ignition threshold limits within the range of the FFI values we analyzed. Thus, a stand-specific monitoring of surface fuel and raw humus layer is recommended so that all potential burning days - whose small number often functions as a limiting factor - could be utilized more effectively, and the targeted impacts of burnings could be ensured.

\section{Conclusions}

393 Our results show that the different ground vegetation fuels differ in their moisture variation and ignition potential. Developmental stage and stand type of the forest affect the moisture variation of the studied fuels. Canadian FWI predicted the FMC of surface layer better than Finnish FFI, so it could be used in Finland. We conclude that, by using additional predictor variables, the ability of forest fire indices to predict fuel moisture could be improved. This could benefit forest fire prevention by enhancing early warning systems and by developing a GIS-based system providing online stand-wise 
FMC estimates of surface fuels, which could be utilized in practical firefighting as well as in

400 prescribed burning.

401

402 Abbreviations

403 CFFWIS Canadian Forest Fire Weather Index System

404 DC Drought Code

405

DMC Duff Moisture Code

406

FFI Finnish Forest Fire Index

407

FFMC Fine Fuel Moisture Code

408

FMC Fuel moisture content

409

FMI Finnish Meteorological Institute

410

FWI Canadian Fire Weather Index

411

412

413 Acknowledgements

414 We thank Antti Kujala and Tuija Toivanen for outstanding field work, Ilari Lehtonen and Ari

415 Venäläinen for providing us FFI and FWI data as well as valuable information on FFI and Sanna

416 Laaka-Lindberg for commenting the manuscript.

417

418 Conflicts of interest: The authors declare no conflicts of interest.

419

420

Declarations of Funding: The data collection of study was partially funded by European Union Fifth

421

Framework projects SPREAD and EUFIRELAB. TA was funded by the Kone Foundation.

422

423

424

425

426 


\section{References}

Ahti T, Hamet-Ahti L, Jalas J (1968) Vegetation zones and their sections in northwestern Europe. Annales Botanici Fennici 5, 169-211.

Busby JR, Whitfield, DWA (1978) Water potential, water content, and net assimilation of some boreal forest mosses. Canadian Journal of Botany 56, 1551-58. https://doi.org/10.1139/b78184

Dimitrakopoulos AP, Bemmerzouk AM, Mitsopoulos ID (2011) Evaluation of the Canadian fire weather index system in an eastern Mediterranean environment. Meteorological. Applications 18, 83-93. https://doi.org/10.1002/met.214

Ferguson SA, Ruthford JE, McKay SJ, Wright D, Wright C, Ottmar R (2002) Measuring moisture dynamics to predict fire severity in longleaf pine forests. International Journal of Wildland Fire 11(4), 267-279. https://doi.org/10.1071/WF02010

Finnish Forestry - Practice and Management (2011) Metsäkustannus, Helsinki. 271 p.

Finnish statistical yearbook of forestry 2014 (2014) Finnish Forest Research Institute. http://urn.fi/URN:ISBN:978-951-40-2506-8

Granström A, Schimmel J (1998) Utvärdering av det kanadensiska brandrisksystemet testbränningar och uttorkningsanalyser. (In Swedish with English abstract: Assessment of the Canadian forest fire danger rating system for Swedish fuel conditions.) P21-244/98. (Rescue Service: Karlstad, Sweden)

Heatwole H (1966) Moisture exchange between the atmosphere and some lichens of the genus Cladonia. Mycologia 58, 148-156. Available at https://www.jstor.org/stable/3756996 [Verified 28 November 2020].

Heikinheimo M, Venäläinen A, Tourula T (1998) A soil moisture index for the assessment of forest fire potential in the boreal zone. In Proceedings of the International Symposium on Applied Agrometeorology and Agroclimatology (Volos, Greece), Office for Official Publication of the European Commission (Luxembourg), NR Dalezios (ed), EUR 18328COST 77, 79, 711. 549-555. 
Hille MG, den Ouden J (2005) Fuel load, humus consumption and humus moisture dynamics in Central European Scots pine stands. International Journal of Wildland Fire 14, 153-159 https://doi.org/10.1071/WF04026

Hille MG, Stephens S (2005) Mixed Conifer Forest Duff Consumption during Prescribed Fires: Tree Crown Impacts. Forest Science 51(5), 417-424. Available at https://nature.berkeley.edu/stephenslab/wp-content/uploads/2015/04/Hille-Stephens-duff-FS[Verified 28 November 2020].

Juvakka M, Viinikainen J, Puputti I, Kuupakko S (1995) Vesijaon tutkimusalue, hoito- ja research area 1994-2003]. Metlan tutkimusmetsien julkaisusarja 5. Vantaa. 228 p. ISSN 1238-0830. (In Finnish).

Kilpeläinen A, Kellomäki S, Strandman H, Venäläinen A (2010) Climate change impacts on forest fire potential in boreal conditions in Finland. Climatic Change 103, 383-398 https://doi.org/10.1007/s10584-009-9788-7

Kuuluvainen T, Lindberg H, Vanha-Majamaa I, Keto-Tokoi P, Punttila P (2019) Low-level retention forestry, certification and biodiversity: case Finland. Ecological Processes 8, 47. https://doi.org/10.1186/s13717-019-0198-0

Lehtonen H, Kolström T (2000) Forest fire history in Viena Karelia, Russia. Scandinavian Journal of Forest Research 15, 585-590. https://doi.org/10.1080/02827580050216833

Lehtonen I, Ruosteenoja K, Venäläinen A, Gregow H (2014) The projected 21st century forest fire risk in Finland under different greenhouse gas scenarios. Boreal Environment Research 19, 127-139. Available at: https://www.researchgate.net/publication/285955800_The_projected_21st_century_forestfire_risk_in_Finland_under_different_greenhouse_gas_scenarios [Verified 28 November 2020].

Lehtonen I, Venäläinen A, Kämäräinen M, Peltola H, Gregow H (2016) Risk of large-scale fires in boreal forests of Finland under changing climate. Natural Hazards and Earth System Sciences 16, 239--253. https://doi.org/10.5194/nhess-16-239-2016 
Lemberg T, Puttonen P (2002) Kulottajan käsikirja. Metsälehti kustannus. Vammalan kirjapaino. (Guide for prescribed burning. Textbook. In Finnish)

Lindberg H, Punttila P, Vanha-Majamaa I (2020) The challenge of combining variable retention and prescribed burning in Finland. Ecological Processes 9, 4 (2020). https://doi.org/10.1186/s13717-019-0207-3

Mäkelä HM, Laapas M, Venäläinen, A (2012) Long-term temporal changes in the occurrence of a high forest fire danger in Finland. Natural Hazards and Earth System Sciences 12, 2591-2601 https://doi.org/10.5194/nhess-12-2591-2012 projections of climatological forest fire danger in Finland. Climate Research 60, 73-85.

Mäkipää R (2000a) Pleurozium schreberi. In: Reinikainen A, Mäkipää R, Vanha-Majamaa I, Hotanen J-P. (eds.) 2000. Kasvit muuttuvassa metsäluonnossa. [Summary in English: Changes in the frequency and abundance of forest and mire plants in Finland since 1950]. Tammi, Jyväskylä. 384 p.

Mäkipää R (2000b) Dicranum. In: Reinikainen A, Mäkipää R, Vanha-Majamaa I, Hotanen J-P. (eds.) 2000. Kasvit muuttuvassa metsäluonnossa. [Summary in English: Changes in the frequency and abundance of forest and mire plants in Finland since 1950]. Tammi, Jyväskylä. $384 \mathrm{p}$.

Mäkipää R (2000c) Hylocomium splendensi. In: Reinikainen A, Mäkipää R, Vanha-Majamaa I, Hotanen J-P. (eds.) 2000. Kasvit muuttuvassa metsäluonnossa. [Summary in English: Changes in the frequency and abundance of forest and mire plants in Finland since 1950]. Tammi, Jyväskylä. 384 p.

Mäkipää R, Heikkinen J (2003) Large-scale changes in abundance of terricolous bryophytes and macrolichens in Finland. Journal of Vegetation Science 14, 497-508. https://doi.org/10.1111/j.1654-1103.2003.tb02176.x 
Mutch, RW, Gastineau OW (1970) Timelag and equilibrium moisture content of reindeer lichen. Res. Pap. INT-76. Ogden, UT: U.S. Department of Agriculture, Forest Service, Intermountain Forest and Range Experiment Station. 8 p. https://doi.org/10.5962/bhl.title.68840 (eds.) 2000. Kasvit muuttuvassa metsäluonnossa. [Summary in English: Changes in the frequency and abundance of forest and mire plants in Finland since 1950]. Tammi, Jyväskylä. $384 \mathrm{p}$.

Okko M (1972) Jäätikön häviämistapa Toisen Salpausselän vyöhykkeessä Lammilla. Summary: Deglaciation in the Second Salpausselka ice-marginal belt at Lammi, South Finland. Terra 84(3), 115-123.

Päätalo ML (1998) Factors influencing occurrence and impacts of fires in Northern European forests. Silva Fennica 32(2), 185-202. https://doi.org/10.14214/sf.695

Péch G (1989) A model to predict the moisture content of reindeer lichen. Forest Science 35, 1014-1028. https://doi.org/10.1093/forestscience/35.4.1137

Péch G (1991) Dew on reindeer lichen. Canadian Journal of Forest Research 21, 1415-1418. https://doi.org/10.1139/x91-198

Peterson W, Mayo J (1975) Moisture stress and its effect on photosynthesis in Dicranum polysetum. Canadian Journal of Botany 53, 2897-2900. Available at https://fdocuments.in/document/moisture-stress-and-its-effect-on-photosynthesis-indicranum-polysetum.html [Verified 28 November 2020].

Pya N (2018) scam: Shape Constrained Additive Models. R package version 1.2-3.

R Core Team (2019) R: A language and environment for statistical computing. Version 3.5. R Foundation for Statistical Computing, Vienna, Austria.

Sandberg DV (1980) Duff reduction by prescribed burning in Douglas-fir. USDA Forest Service Research Paper PNW-272, 18 p. https://doi.org/10.2737/PNW-RP-272

San-Miguel-Ayanz J, Carlson JD, Alexander M, Tolhurst K, Morgan G, Sneeuwjagt R, Dudley M (2003) Current methods to assess fire danger potential. In Wildland Fire Danger Estimation and Mapping.The Role of Remote Sensing Data, Chuvieco E (ed). World Scientific 
Publishing: Singapore; 21-61. Available at https://pdfs.semanticscholar.org/da16/f999aff0083cfee5820cfad43a8d6d1e4c41.pdf [Verified 28 November 2020].

Schimmel J, Granström A (1997) Fuel succession and fire behavior in the Swedish boreal forest. Canadian Journal of Forest Research 27, 1207-1216. https://doi.org/10.1139/x97-072 Sjöström J, Plathner FV, Granström A (2019) Wildfire ignition from forestry machines in boreal Sweden. International Journal of Wildland Fire 28(9), 666-677. https://doi.org/10.1071/WF18229

Tamminen P (1991) Kangasmaan ravinnetunnusten ilmaiseminen ja viljavuuden alueellinen vaihtelu. Summary: Expression of soil nutrient status and regional variation in soil fertility of forested sites in southern Finland. Folia Forestalia 777. 40 p. http://urn.fi/URN:ISBN:951$40-1170-8$

Tanskanen H, Venäläinen A, Puttonen P, Granström A (2005) Impact of stand structure on surface fire ignition potential in Picea abies and Pinus sylvestris forests in southern Finland. Canadian Journal of Forest Research 35, 410-420. https://doi.org/10.1139/X04-188

Tanskanen H, Granström A, Venäläinen A, Puttonen P (2006) Moisture dynamics of moss dominated surface fuel in relation to the structure of Picea abies and Pinus sylvestris stands. Forest Ecology and Management. 226, 189-198. doi:10.1016/j.foreco.2006.01.048

Tonteri T, Salemaa M, Rautio P (2013) Changes of understorey vegetation in Finland in 19852006. In: Merilä, P. \& Jortikka, S. (eds.). Forest Condition Monitoring in Finland - National report. The Finnish Forest Research Institute. [Online report]. http://urn.fi/URN:NBN:fi:metla-201305087583.

Vajda A, Venäläinen A, Suomi I, Junila P, Mäkelä HM (2014) Assessment of forest fire danger in a boreal forest environment: description and evaluation of the operational system applied in Finland. Meteorological Applications 21, 879-887. https://doi.org/10.1002/met.1425

Van Wagner CE (1987) Development and Structure of the Canadian Forest Fire Weather Index System; Forestry Technical Report 35; Canadian Forestry Service: Ottawa, ON, Canada, 

November 2020]. Van Wagner CE, Pickett TL (1985) Equations and FORTRAN program for the Canadian Forest Fire Weather Index System. Canadian Forestry Service, Petawawa National Forestry Institute, Chalk River, Ontario. Forestry Technical Report 33. 18 p. Available at https://cfs.nrcan.gc.ca/publications?id=19973 [Verified 28 November 2020]. Vasander H, Lindholm T (1985) Fire intensities and surface temperatures during prescribed burning. Silva Fennica 19(1), 1-15. https://doi.org/10.14214/sf.a15406 Springer, $467 \mathrm{p}$.

Wallenius T (2004) Fire histories and tree ages in unmanaged boreal forests in Eastern Fennoscandia and Onega peninsula. Academic Dissertation, June 2004.University of Helsinki,

Wallenius T (2011) Major decline in fires in coniferous forests - reconstructing the phenomenon and seeking for the cause. Silva Fennica 45, 139-155. https://doi.org/10.14214/sf.36 Yearbook of forest statistics 1990-1991 (1992) Finnish Forest Resource Institute. http://urn.fi/URN:ISBN:951-40-1205-4 516; https://doi.org/10.3390/f11050516

\section{9}


594 Table 1. The sampled stands. In clear-cut areas the dominant tree species refers to species of the pre-

595 cut stand. Pine: Pinus sylvestris, spruce: Picea abies, birch: Betula spp.

596

\begin{tabular}{lllllll}
\hline Stand & Developmental stage & Stand type & $\begin{array}{l}\text { Age, } \\
\text { years }\end{array}$ & $\begin{array}{l}\text { Average } \\
\text { height, } \\
\text { meters }\end{array}$ & $\begin{array}{l}\text { Standing stem } \\
\text { volume: cubic } \\
\text { meters/hectare }\end{array}$ & $\begin{array}{l}\text { Standing tree species } \\
\text { percentages by volume } \\
\text { (pine/spruce/birch) }\end{array}$ \\
\hline SXC1 & clear-cut & sub-xeric/pine & 0 & 0 & 0 & - \\
SXC2 & clear-cut & sub-xeric/pine & 0 & 0 & 0 & - \\
SXC3 & clear-cut & sub-xeric/pine & 0 & 0 & 0 & - \\
SXM1 & mature & sub-xeric/pine & 90 & 24 & 210 & $90 / 10 / 0$ \\
SXM2 & mature & sub-xeric/pine & 120 & 26 & 250 & 100 \\
SXM3 & mature & sub-xeric/pine & 120 & 25 & 240 & 100 \\
MC1 & clear-cut & mesic/spruce & 0 & 0 & 0 & - \\
MC2 & clear-cut & mesic/spruce & 0 & 0 & 0 & - \\
MC3 & clear-cut & mesic/spruce & 0 & 0 & 0 & - \\
MM1 & mature & mesic/spruce & 75 & 26 & 260 & $10 / 80 / 10$ \\
MM2 & mature & mesic/spruce & 90 & 28 & 310 & $10 / 90 / 0$ \\
MM3 & mature & mesic/spruce & 90 & 27 & 290 & $10 / 90 / 10$ \\
\hline
\end{tabular}


Table 2. Parametric coefficients for factor variables in the models. Estimates for the developmental 624 stage (Dev. Stage) are relative to clear-cut area, and site type relative to mesic site type. Hylocomium 625 and Cladonia occurred only on a single type.

626

\begin{tabular}{|c|c|c|c|c|c|c|c|}
\hline Layer & Species & Variable & Estimate & Std. Error & $\mathrm{t}$ & $\mathrm{p}$ & \\
\hline \multirow[t]{3}{*}{ Surface } & Pleurozium & Intercept & 4.75 & 1.72 & 2.76 & 0.006 & $* *$ \\
\hline & & Dev. stage mature forest & 2.24 & 2.42 & 0.92 & 0.356 & \\
\hline & & Site type sub-xeric & -0.23 & 0.16 & -1.47 & 0.144 & \\
\hline \multirow[t]{3}{*}{ Surface } & Dicranum & Intercept & 5.00 & 0.90 & 5.56 & $<0.001$ & $* * *$ \\
\hline & & Dev. stage mature forest & 0.58 & 0.91 & 0.64 & 0.523 & \\
\hline & & Site type sub-xeric & -0.10 & 0.10 & -0.98 & 0.327 & \\
\hline \multirow[t]{2}{*}{ Surface } & Hylocomium & Intercept & 3.98 & 0.23 & 17.36 & $<0.001$ & $* * *$ \\
\hline & & Dev. stage mature forest & 2.85 & 2.54 & 1.12 & 0.266 & \\
\hline \multirow[t]{2}{*}{ Surface } & Cladonia & Intercept & 3.63 & 0.17 & 21.11 & $<0.001$ & $* * *$ \\
\hline & & Dev. stage mature forest & 2.13 & 2.58 & 0.82 & 0.412 & \\
\hline \multirow[t]{3}{*}{ Raw humus } & Pleurozium & Intercept & 5.39 & 0.21 & 26.01 & $<0.001$ & $* * *$ \\
\hline & & Dev. stage mature forest & 0.13 & 0.35 & 0.36 & 0.719 & \\
\hline & & Site type sub-xeric & -0.20 & 0.05 & -4.24 & $<0.001$ & $* * *$ \\
\hline \multirow[t]{3}{*}{ Raw humus } & Dicranum & Intercept & 4.96 & 0.41 & 12.16 & $<0.001$ & $* * *$ \\
\hline & & Dev. stage mature forest & 0.73 & 0.51 & 1.43 & 0.156 & \\
\hline & & Site type sub-xeric & -0.16 & 0.06 & -2.44 & 0.016 & $*$ \\
\hline \multirow[t]{2}{*}{ Raw humus } & Hylocomium & Intercept & 5.30 & 0.37 & 14.50 & $<0.001$ & $* * *$ \\
\hline & & Dev. stage mature forest & 0.43 & 0.47 & 0.92 & 0.363 & \\
\hline \multirow[t]{2}{*}{ Raw humus } & Cladonia & Intercept & 4.76 & 0.09 & 54.53 & $<0.001$ & $* * *$ \\
\hline & & Dev. stage mature forest & 0.62 & 0.28 & 2.24 & 0.027 & * \\
\hline
\end{tabular}

Significant variables $(\mathrm{p}<0.05)$ are in bold 
Table 3. Significance of smoother terms and plot-level random effects

\begin{tabular}{|c|c|c|c|c|c|}
\hline Layer & Species & Smoother term & $\mathrm{F}$ & $\mathrm{p}$ & \\
\hline \multirow[t]{12}{*}{ Surface } & Pleurozium & s(FFI) $\times$ Dev. stage clearcut & 32.18 & $<0.001$ & $* * *$ \\
\hline & & s(FFI) $\times$ Dev. stage mature forest & 27.33 & $<0.001$ & $* * *$ \\
\hline & & plot (random effect) & 3.09 & $<0.001$ & $* * *$ \\
\hline & Dicranum & s(FFI) x Dev. stage clearcut & 27.37 & $<0.001$ & $* * *$ \\
\hline & & s(FFI) $\times$ Dev. stage mature forest & 29.96 & $<0.001$ & $* * *$ \\
\hline & & plot (random effect) & 0.04 & 0.393 & \\
\hline & Hylocomium & s(FFI) $\times$ Dev. stage clearcut & 15.18 & $<0.001$ & $* * *$ \\
\hline & & s(FFI) $x$ Dev. stage mature forest & 12.75 & $<0.001$ & $* * *$ \\
\hline & & plot (random effect) & 0.31 & 0.326 & \\
\hline & Cladonia & s(FFI) x Dev. stage clearcut & 28.54 & $<0.001$ & $* * *$ \\
\hline & & s(FFI) x Dev. stage mature forest & 11.76 & $<0.001$ & $* * *$ \\
\hline & & plot (random effect) & 0.00 & 0.841 & \\
\hline \multirow[t]{12}{*}{ Raw humus } & Pleurozium & s(FFI) x Dev. stage clearcut & 11.07 & $<0.001$ & $* *$ \\
\hline & & $\mathrm{s}(\mathrm{FFI}) \times \mathrm{Dev}$. stage mature forest & 2.49 & 0.111 & \\
\hline & & plot (random effect) & 0.19 & 0.366 & \\
\hline & Dicranum & s(FFI) x Dev. stage clearcut & 5.93 & 0.004 & $* *$ \\
\hline & & $\mathrm{s}(\mathrm{FFI}) \times$ Dev. stage mature forest & 2.36 & 0.118 & \\
\hline & & plot (random effect) & 1.73 & 0.023 & * \\
\hline & Hylocomium & $\mathrm{s}(\mathrm{FFI}) \times$ Dev. stage clearcut & 3.66 & 0.060 & \\
\hline & & s(FFI) x Dev. stage mature forest & 6.77 & 0.011 & $*$ \\
\hline & & plot (random effect) & 0.00 & 0.815 & \\
\hline & Cladonia & s(FFI) $\times$ Dev. stage clearcut & 30.09 & $<0.001$ & $* * *$ \\
\hline & & s(FFI) $x$ Dev. stage mature forest & 5.18 & 0.026 & * \\
\hline & & plot (random effect) & 2.84 & 0.017 & $*$ \\
\hline
\end{tabular}


652 Table 4. Performance of the Finnish Forest Fire Index (FFI) compared to the Canadian Fire Weather 653 Index (FWI) as a predictor of FMC in different layers, measured as pseudo-R2.

654

\begin{tabular}{lll}
\hline \multirow{2}{*}{ Surface layer } & $\mathrm{FFI}$ & $\mathrm{FWI}$ \\
\hline & $\mathrm{R}^{2}$ & $\mathrm{R}^{2}$ \\
\cline { 2 - 3 } & 0.55 & 0.64 \\
Pleurozium & 0.46 & 0.54 \\
Dicranum & 0.6 & 0.69 \\
Hylocomium & 0.45 & 0.52 \\
Cladonia & &
\end{tabular}

\begin{tabular}{lll} 
Raw humus & $\mathrm{FFI}$ & $\mathrm{FWI}$ \\
\hline & $\mathrm{R}^{2}$ & $\mathrm{R}^{2}$ \\
\cline { 2 - 3 } & 0.26 & 0.25 \\
Pleurozium & 0.36 & 0.34 \\
Dicranum & 0.35 & 0.36 \\
Hylocomium & 0.42 & 0.34 \\
Cladonia & & \\
& & \\
\hline
\end{tabular}


671 Table 5. The potential fire hazard days (defined as fuel moisture content values under 25\%) of studied

672 surface layer materials, stand types and developmental stages. (MT= mesic stand, SX= sub-xeric

673 stand, $\mathrm{C}=$ clear-cut area, $\mathrm{M}=$ mature stand, FFI pred = the potential days of ignition predicted by

674 Finnish Forest Fire Index (FFI), index values> 4)

675

676

\begin{tabular}{|c|c|c|c|c|c|c|c|c|c|c|}
\hline & MTC & $\overline{\text { MTM }}$ & SXC & SXM & MT & $5 X$ & $\bar{C}$ & $\bar{M}$ & FFFI pred & Total \\
\hline Pleurozium & $54 \%$ & $8 \%$ & $41 \%$ & $31 \%$ & $28 \%$ & $36 \%$ & $47 \%$ & $20 \%$ & $6 \%$ & $32 \%$ \\
\hline Dicranum & $32 \%$ & $0 \%$ & $27 \%$ & $8 \%$ & $14 \%$ & $18 \%$ & $29 \%$ & $4 \%$ & $6 \%$ & $16 \%$ \\
\hline Hylocomium & $54 \%$ & $4 \%$ & & & $22 \%$ & & $54 \%$ & $4 \%$ & $6 \%$ & $22 \%$ \\
\hline Cladonia & & & $71 \%$ & $20 \%$ & & $45 \%$ & $71 \%$ & $20 \%$ & $6 \%$ & $45 \%$ \\
\hline Total & $45 \%$ & $4 \%$ & $46 \%$ & $20 \%$ & $21 \%$ & $33 \%$ & $46 \%$ & $12 \%$ & $6 \%$ & $28 \%$ \\
\hline $\mathrm{FFI}>4$ & & & & & & & & & $6 \%$ & \\
\hline $\mathrm{FFI}<4$ & & & & & & & & & $94 \%$ & \\
\hline
\end{tabular}

677

678

679

680

681 Figure 1. Location of sampled stands

682 Figure 2. The observed fuel moisture contents (FMC) and Finnish Forest Fire Index (FFI) values on

683 sampling days. Note the different y-axes.

684 Figure 3. The predicted fuel moisture content (\%) of each studied species, by stand type and

685 developmental stage, as a function of Finnish Forest Fire Index (FFI). Dotted lines show the 25-35\%

686 moisture content.

687 Figure 4. The predicted fuel moisture content (\%) by studied species, as a function of Finnish Forest

688 Fire Index (FFI) on different stand types and developmental stages. Dotted lines show the 25-35\%

689 moisture content.

690 


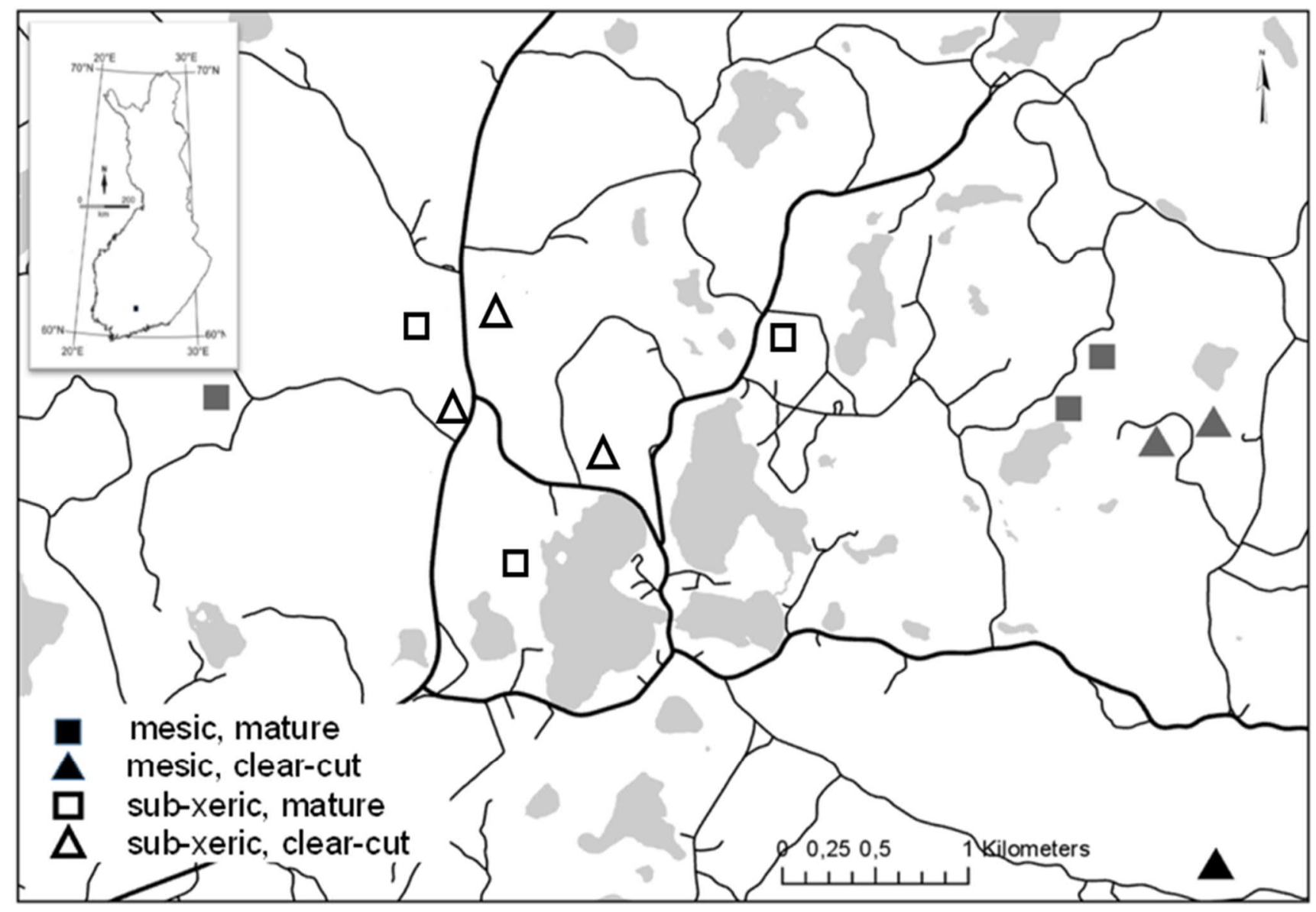

691

692 Figure 1.

693

694 

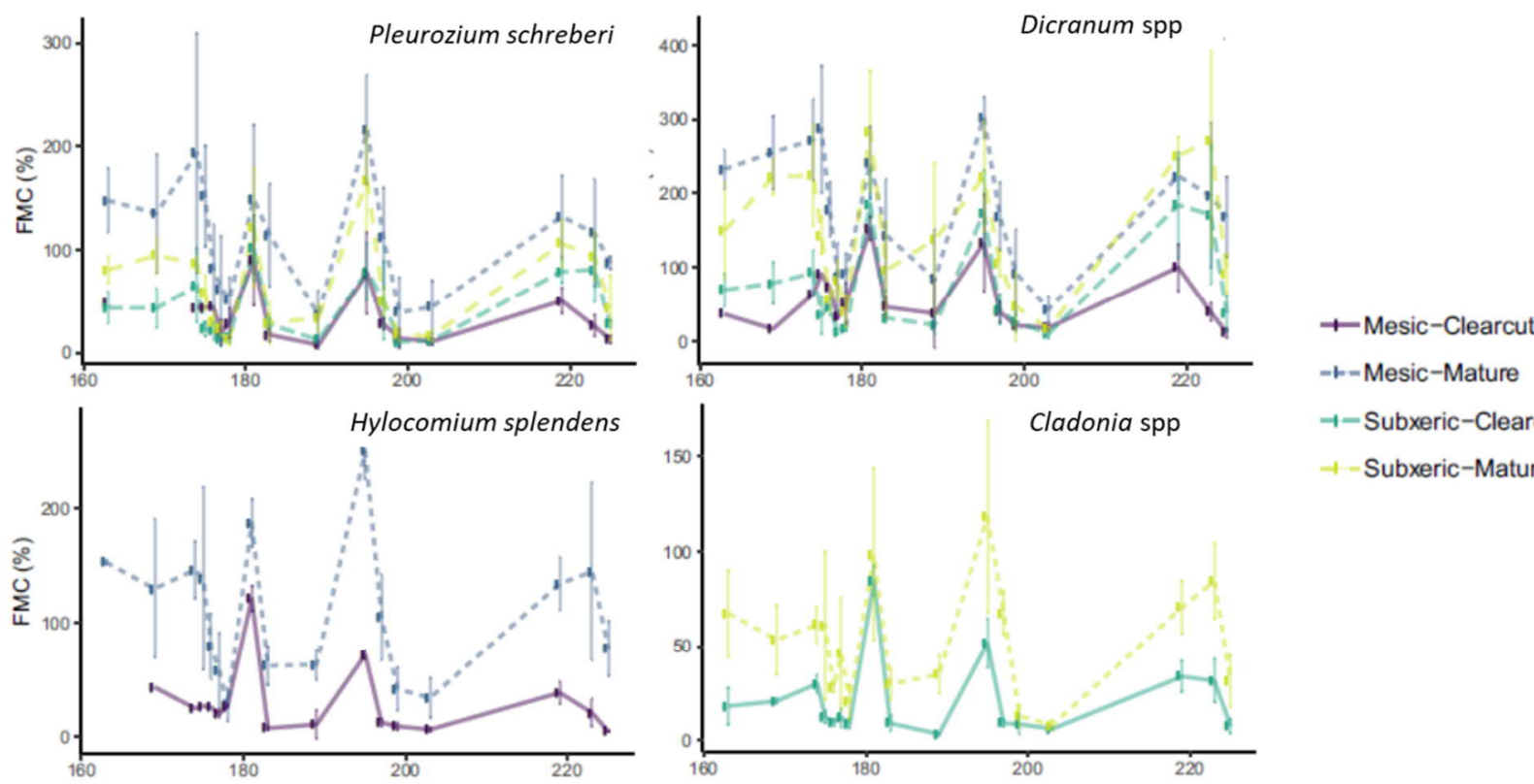

-1-Subxeric-Clearcut

-1 -Subxeric-Mature
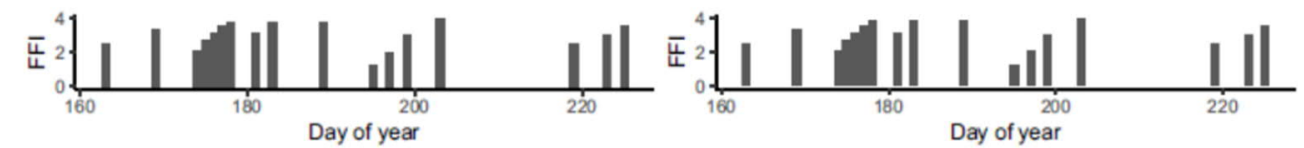

696

697

698

Figure 2.

699

700

701 


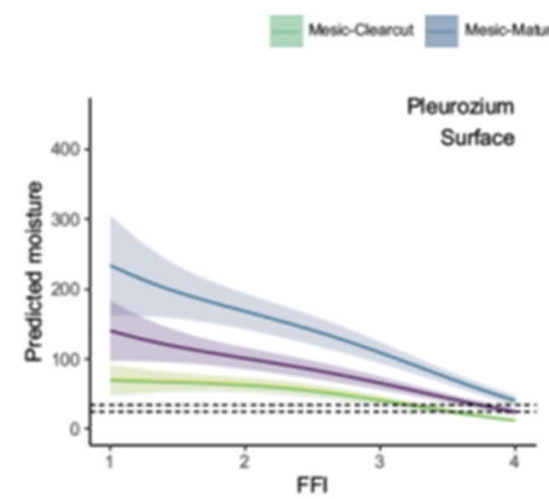

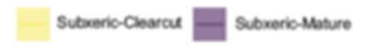
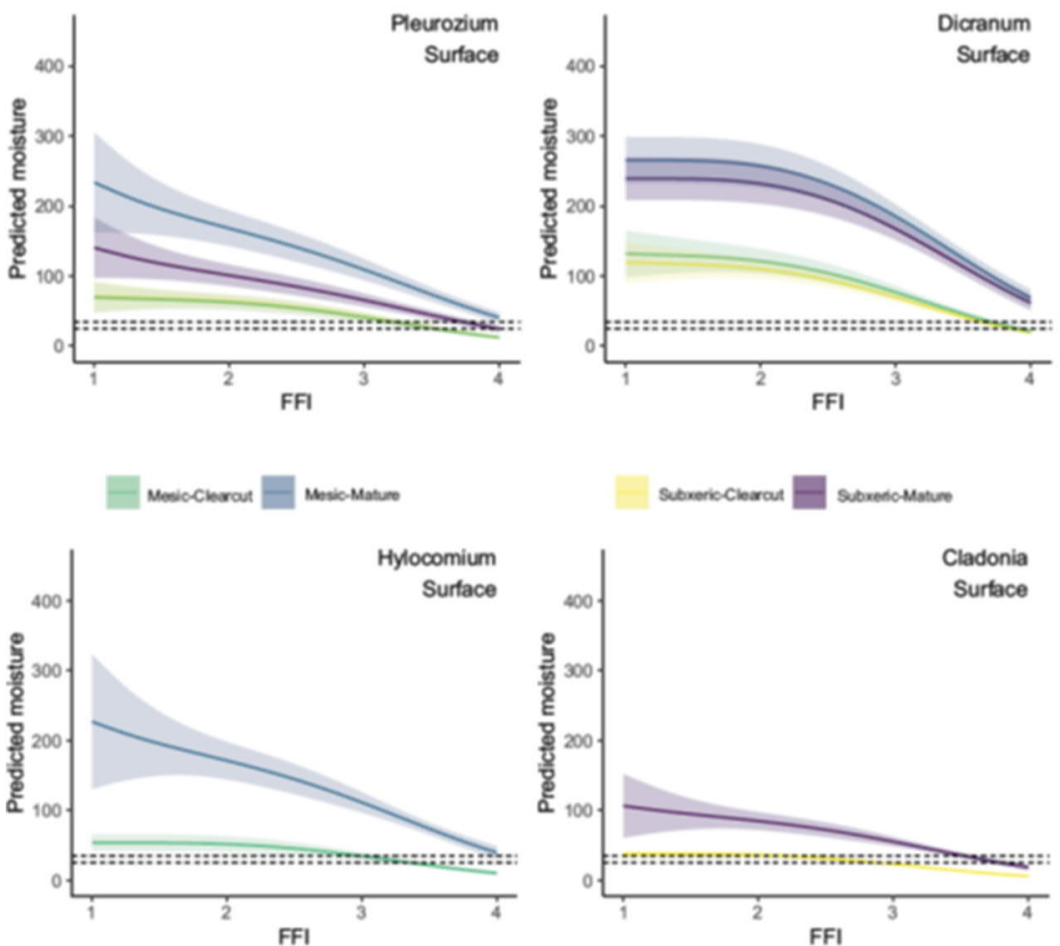

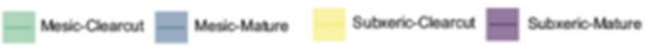
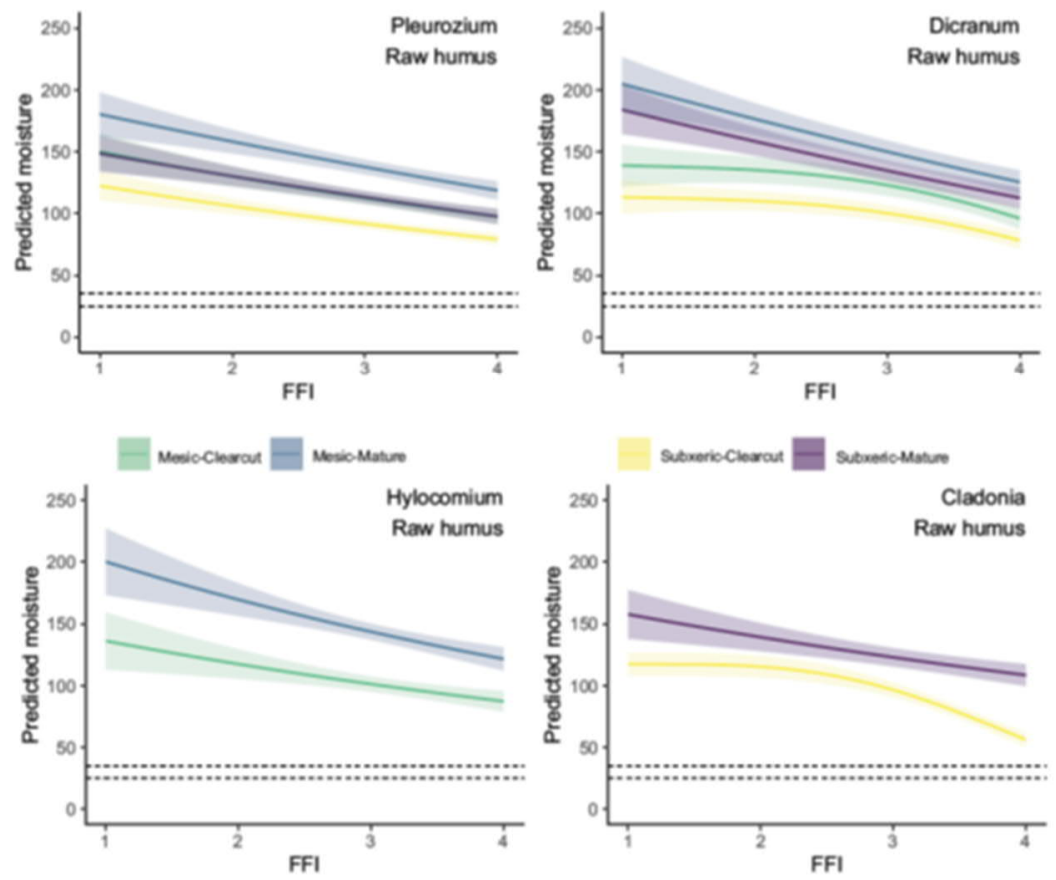

Figure 3. 

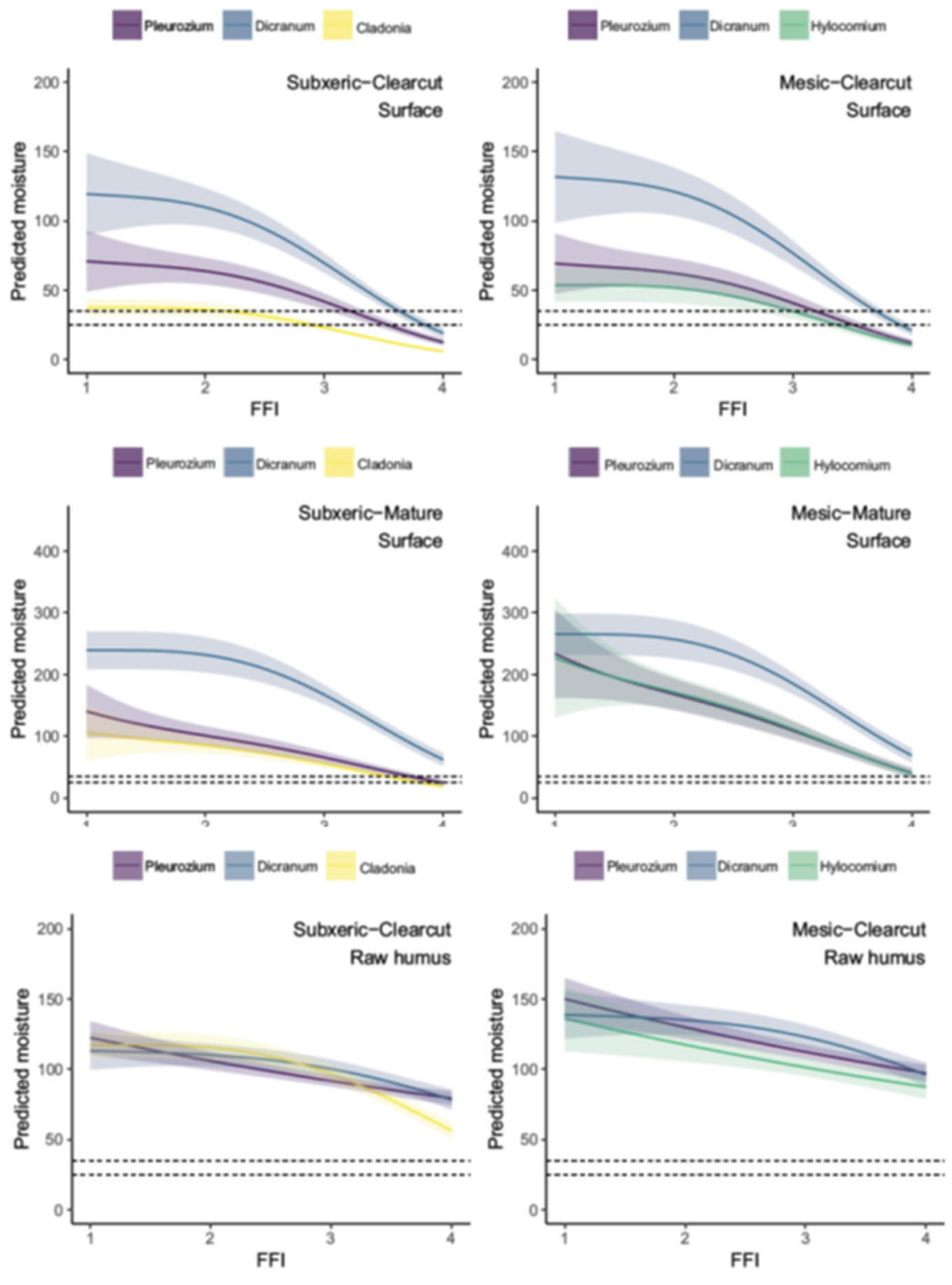

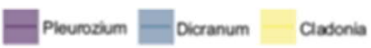
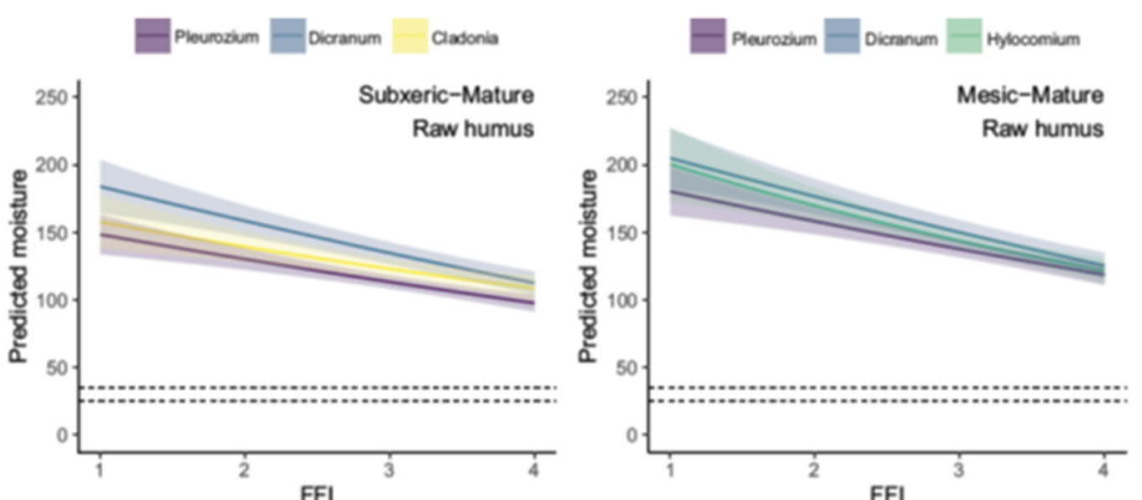

Figure 4. 